\title{
THE DETERMINANTS OF THE QUALITY OF THE SALES-MARKETING INTERFACE IN A MULTINATIONAL CUSTOMER BRAND FOCUSED COMPANY: THE LATIN AMERICAN BRANCHES
}

\author{
Teresa Cometto, Universidad ORT Uruguay, Uruguay \\ Gaston J. Labadie, Universidad ORT Uruguay, Uruguay \\ Miguel Palacios, Universidad Politécnica de Madrid, Spain
}

\begin{abstract}
Customer evolution and changes in consumers, determine the fact that the quality of the interface between marketing and sales may represent a true competitive advantage for the firm.

Building on multidimensional theoretical and empirical models developed in Europe and on social network analysis, the organizational interface between the marketing and sales departments of a multinational high-growth company with operations in Argentina, Uruguay and Paraguay is studied. Both, attitudinal and social network measures of information exchange are used to make operational the nature and quality of the interface and its impact on performance.
\end{abstract}

Results show the existence of a positive relationship of formalization, joint planning, teamwork, trust and information transfer on interface quality, as well as a positive relationship between interface quality and business performance. We conclude that efficient design and organizational management of the exchange network are essential for the successful performance of consumer goods companies that seek to develop distinctive capabilities to adapt to markets that experience vertiginous changes.

\section{INTRODUCTION}

This paper studies the factors which influence the quality of marketing and sales departments' interface and its effect on business performance within the context of a post-crisis Latin American market, characterized by profound changes in consumers, competitors and clients.

Homburg and Jensen (2007), use the term "quality of cooperation" between marketing and sales (instead of "integration"), defined as the extension where there is systematic collaboration between marketing and sales, characterized by a unity of efforts. Rouziès et al. (2005) define the marketing and sales interface as a dynamic process by which two functional areas create more value for the firm by working together than they would if they worked separately. However, considering the criticisms made to and the ambiguity of the term "integration" (Homburg and Jensen 2007), the terms "quality of marketingsales interface" will be used herein.

While extensive research has been conducted on interdepartmental relations between Marketing and Production, Research and Development, Finance and Logistics, research on the interface between the marketing and sales function has only been done recently (Homburg et al. 2008) particularly in terms of its impact on business performance (Le Meunier-FitzHugh and Piercy 2007). The theoretical and empirical literature that has treated marketing and sales as separate units has either considered typologies of the interface and the management issues related to different stages within the organization (Webster 1997; Day and Montgomery 1999; Kotler et al. 2006; Homburg et al. 2008) or examined the integrative mechanisms and their relationship with business performance (Dewsnap and Jobber 2000; Dewsnap et al. 2004; Rouziès et al. 2005). From a theoretical point of view these integration mechanisms can be examined considering structure, processes or systems, culture and people. Homburg, Jensen and Krohmer (2008) have carried out one of the most recent and comprehensive empirical study which develops a taxonomy of interfaces, creating a multidimensional model which integrates simultaneously dimensions which had previously been studied as isolated elements: power (Homburg, Workman and Krohmer 1999), shared information and integrative mechanisms (Cespedes 1995), cognitive orientation and knowledge (Cespedes 1995; Montgomery and Webster 1997). The above mentioned multidimensional model studies those five domains and identifies superior configurations called "Brand-focused Professionals" (consumer goods companies with differentiated marketing and sales functions), characterized by top quality collaboration systems and market performance.

The present study performs, to our knowledge for the first time in the literature, an empirical analysis of the above mentioned model within one of the most effective configurations in terms of interface quality, the "Brand Focused Professional" companies, and examines the factors affecting the marketing and sales interface and the network information exchange dynamics. It tests the model in a multinational packaged consumer goods company, operating in the Latin America's 
Southern Cone, with a record of outstanding performance and a global recognition for its excellence in execution, extending the original model with a relational or social network component.

\section{Interface as an information transfer network}

Up till now, the marketing and sales interface has not been considered from a relational view point and barely considered in the social network literature (Betts and Stouder 2004), although this approach has been used to analyze supply chain interfaces (Carter et al. 2007).

A network is a set of actors who are connected with one another through arches which carry out transactions. Mutual profitability is only possible if resources are joined (coordination) and the parties agree to give up the right to follow their own interests at the expense of general interests (collaboration). Networks include three critical components: knowledge, trust (cooperation and reciprocity of a long term continuous exchange relationship), speed and the ability to disseminate new information (Powell 1990; Wasserman and Faust 2008). To understand economic exchange, "embeddedness" is a key concept in network theory (Granovetter, 1985), which implies that every economic behavior is necessarily embedded in a larger social context and the results are affected by dyadic relationships between actors and the relationship network structure. Relational "embeddedness" is the dimensional extension of relationship quality (centrality and power) and it is an indicator of how actors connect with each other and how much influence they exert on economic performance (Uzzi 1996). Structural "embeddedness" is an analytical concept which examines how resource or information flow is organized in terms of structure within the structure of ties between actors (density). Considering findings resulting from research on other interfaces, particularly supply chain management (Carter et al. 2007; Borgatti and Li 2009) and the configuration of Japanese "keiretsu" networks (Wakabayashi 2003), we examine how marketing and sales can develop relational trust, fostering cooperation and coordination (Rodríguez and Wilson 1999), limiting opportunistic behavior and reducing transaction costs (Uzzi 1997).

The network approach then, provides a natural conceptual complement and a way to make operational some of the concepts developed in Rouziès et al. (2005) framework and Homburg et al. (2008) model.

\section{THEORETICAL MODEL AND HYPOTHESIS}

Our model includes two sets of relationships. The first set of relationships describes the effects of network variables on trust and performance, analyzing network variables such as density, centrality and power. Power is best understood from a network approach since it is inherently relational. If a system has low density, not much power can be exerted, while the opposite is true for high density systems. Network position (Bonacich 1991) is linked to the ability to absorb knowledge and loosen-up perspective, and at the same time it is related to intensive knowledge task performance which to a certain degree depend on the collection of proper information to solve new and challenging problems. According to the "embeddedness" approach on organizational control, trust enabled by relational proximity (Hess 2004), fosters the network learning process through a complex social phenomenon which includes knowledge, emotions, reputation, appearance, identities, institutions and power relationships (Glückler 2005).

In the case of the marketing and sales interface, trust is built upon social interactions, cultural integration between individuals with different "thought worlds" (Homburg and Jensen 2007) and the support of regulatory frameworks and institutional processes (Child and Faulkner 1998), that is to say, a combination of trust based on the institution and trust based on interaction. Wakabayashi (2003) develops and proves empirically that a high number of relationships or ties (relational "embeddedness") promote a positive assessment of relational trust (reciprocity) just as the density of the network (structural embeddedness) expands this effect (trust in skills and performance, reputation). Rodríguez and Wilson (1999) prove that a high level of structural union determines a high level of trust in inter-company partnerships and Dawes and Massey (2006, 2007) indicate a positive relationship between trust and the perception of interface quality. Summarizing the above:

H1 Organizational trust is positively associated with a firm's network: (a) density; (b) centrality; (c) power.

$\mathrm{H} 2$ Organizational trust is positively associated with the firm quality of marketing and sales interface

The second set of relationships is based on the multidimensional model developed empirically in Europe by Homburg and his colleagues (2008) which defines the dimensions affecting marketing and sales interface in the different taxonomies. Knowledge and orientation differentiates these firms and establish them as consumer and customer experts respectively, 
while structural unions (teamwork) are integrative mechanisms (Workman et al. 1998). Summarizing the above:

H3 (a) Teamwork skills are positively associated with the firm's quality of marketing and sales interface

H3 (b) Market and product knowledge of marketing and sales are positively associated with the firm's quality of marketing and sales interface

Data dissemination and communication is a dimension described by Homburg et al. (2008) as a key factor to organizational learning (Kotler et al. 2006). The hypothesis established by Rouziès and his colleagues (2005) shows the existence of a positive relationship between formal and informal communication and integration. In fact, bidirectional communication has a strong negative effect on conflict (Dawes and Massey 2005; Kotler et al. 2006). Summarizing the above:

H4 (a) Information sharing is positively associated with the firm's quality of marketing and sales interface

H4 (b) Joint planning is positively associated with the firm's quality of marketing and sales interface

H4 (c) Formalization is positively associated with the firm's quality of marketing and sales interface

Power is another domain which reflects how the influence over market-related activities is divided amongst the marketing and sales functions (Homburg et al., 1999). In the organization under study marketing and sales department have equal weight, hierarchical level and participation in the Company Board. Within this structure, power is probably more dependent on exchange relationships, thus it is measured using the network approach (Hypothesis H1c).

Finally, there is empirical evidence that relates the quality of cooperation between the marketing and sales functions and business performance (Dewsnap et al. 2000, 2004, Rouziès et al. 2005; Le Meunier-FitzHugh and Piercy 2007; Homburg et al. 2008). Summarizing the above:

H5 the firm's quality of marketing and sales interface is positively associated with market business performance, achieving better competitive results.

\section{COMPANY SELECTION AND DATA COLLECTION}

The empirical study is conducted at a multinational consumer goods company in one of its Latin America's southern cone branches (Argentina, Uruguay and Paraguay). The company has a worldwide presence and a large market share for participating categories.

In South America, the growth of the southern cone region stood out in 2006 (17\%), 2007 (21\%) and 2008 (26\%), as one of highest growth rates in the world compared to other regions (America and the world 5-7\%) affecting positively the market share performance in the most relevant categories where the firm occupies the first position with regard to its competitors. According to the study conducted by Homburg and his colleagues (2008), the taxonomic group to which this type of consumer goods companies belong ("Brand-Focused Professionals") is characterized by the highest levels of formalization, joint planning, team work and shared information, as well as the highest levels of market and product knowledge. This industry has a strong strategic focus on brands, but also an intense development of the sales function (Homburg et al. 2000). The research surveyed managers within both - sales and marketing departments - of the same firm in different countries, Argentina, Uruguay and Paraguay, based on a data base supplied by the firm. A self-administered questionnaire was used as the data collection instrument, and it was sent via e-mail to each of the people included in each country's data base. Every person contacted received an introduction on the project's objective, as well as an information confidentiality clause. The questionnaire and its rating scales were based on literature review and were previously assessed through semi-structured qualitative interviews. The questionnaire had 3 modules: characterization of the firm's respondent, marketing and sales network within work teams and the assessment of marketing and sales interaction within work teams. In order to evaluate the network hypothesis, reciprocal information transfer relationships (who is information required from? Or, who goes in search of information?) were collected using a positional chart (Krackhardt 1990).

After quality control of the data, 43 valid answers were received out of a total of 75 from all three countries, over a period of less than 10 days, with similar quotas for marketing and sales. These cases represent a high rate 57\% response and enough cases to enable the use of statistical analysis techniques (Homburg et al. 2007; Mertler and Vannata 2005). The marketing 
and sales responses came from a population with the same distribution ( $\mathrm{Z}$ de Kolmogorov Smirnov's Non-Parametric Test) and non-significant differences (Non-parametric Test from the $U$ of Mann-Whitney), all of which enabled us to unite all marketing and sales responses under one unique sample.

\section{VARIABLES VALIDATION AND MEASUREMENT}

Factor consistency evaluation was carried out in a first stage using Exploratory Factor Analysis (principal axis factoring for non-normal data, Costello and Osborne 2005). Ordinal factor reliability was estimated applying SEM (Structural Equation Modeling) polychoric correlations (non-continuous ordinal data on the Likert scale) (Oliden and Zumbo 2008).

Business performance was assessed using 3 items. Informants were asked to indicate the extent to which the business unit's profit, growth and market share outcomes had occurred over the past year , based on 5-point scales (anchors: "1 = "Strongly disagree", 5 = "strongly agree") (Homburg and Jensen 2007; Homburg et al. 2008; Trade audits Nielsen/CCR). All three items show low convergence (alpha $=0.76$ ). This result is due to the fact that the respondents are aware of the firm's growth and profitability but they don't have this information on competitors'. Considering high factor loading (> 0.6, Costello and Osborne, 2005), the performance construct is substituted by the market share growth variable which is consistent with the marketing and sales managers' objectives and is verified through the Nielsen/CCR trade audits information (2008).

The quality of the interface was assessed using seven items (Ellinger 2000; Homburg and Jensen 2007; Homburg et al. 2008). All seven items show high convergence $(\alpha=0.91)$. Team working was assessed using six items (Cespedes 1996; Homburg et al. 2008). All six items show high convergence $(\alpha=0.85$ ). Information sharing was assessed using three items (Jaworski and Kohli 1993; Homburg et al. 2008). All three items show high convergence $(\alpha=0.94)$. Formalization was assessed using seven items (Ruekert and Walker 1987; Dewsnap and Jobber 2002; Homburg et al. 2008), showing high convergence $(\alpha=$ 0.85). Joint planning was assessed using four items (Piercy 1989, Homburg et al. 2008), showing high convergence $(\alpha=$ 0.87). Market and product knowledge was assessed using six items (Homburg et al 2008), showing both low convergence (marketing knowledge $\alpha=0.60$, sales knowledge $\alpha=0.75$ ). Sales knowledge can be improved by eliminating the customer knowledge variable $(\alpha=0.81)$; however, due to the fact that it is an extremely relevant variable, this would not be feasible. Additionally, other indexes composed of the difference between marketing and sales knowledge were tested (Homburg and Jensen 2007), but convergence remained inferior to 0.8 . This construct's weakness disables hypothesis validation or rejection.

Network variables are calculated considering the relationship between pairs of individuals who work in the marketing and sales functions (dyadics) in each country as units of analysis. For each pair, we measured the extension in which the individual in position i looks for and sends information on the individual in position $\mathrm{j}$, using a matrix $\mathrm{NxN},(0.1)$. In order to reduce response accuracy problems, the reciprocal path was considered (giving and receiving information) and then the average was calculated (Borgatti et al. 2009). Density (number of ties related to total possible network ties [n(n-1)/2], centrality (biggest tie quantity, lowest distance, exposure index, strategic influence opportunity and leadership) and power (centrality negatively weighted with strong ties and positively weighted with weak ties) were calculated using Ucinet 6 software (Borgatti et al. 2002; Hanneman 2002). Trust was assessed using three items (Wakabayashi 2003), showing high convergence $(\alpha=0.85)$.

\section{Data Analysis}

Results confirmed the specialization in marketing and sales knowledge ( $>4$ knowledge of clients through sales and knowledge of brands through marketing) as well as in team work, joint planning, mutual support, trust and performance, which are typical of "brand focused professional" firms and are consistent with the taxonomy defined by Homburg et al. (2008) and empirically validated in Europe.

The analysis of interface networks by country enables us to describe and understand information flow and allow us to make any necessary structural corrections. In the smaller countries, Uruguay and Paraguay, networks show high density levels close to their highest potential, and a high level of variation (Standard deviation close to 0.5 ). Higher density roles have a higher level of hierarchy and play an integrative role between the two departments (customer marketing). In terms of centrality, actors within the Argentine network have more ties to other actors, and are therefore less dependent on other individuals since they have alternative ways of satisfying needs or obtaining more resources. Centralization is low in all networks, displaying low heterogeneity. The most influential positions are once again those with a higher hierarchy level and they play a coordinating role between the two departments (customer marketing, visibility and trade category specializations). Once the concepts were made operational, we were able to test the relationship between them in the model, against the 
obtained measurement data, to determine how well the model fits the data. A confirmatory factor analysis was conducted using SEM (Structural Equation Modeling) in order to understand the relationship between studied variables and latent variables which are the unobserved cause of the aforementioned ones. In this study, SEM (Fox 2006) is applied using R software, a package that provides basic structural equation modeling facilities, including the ability to fit structural equations in observed variable models by two-stage least squares (assuming multinormality). As a result we obtained a more strict analysis of the researched model, using the most common measures of fit: Chi-Square, Root Mean Square Error of Approximation (RMSEA), Comparative Fit Index (CFI), Tucker-Lewis, Bentler and Bentler-Bonnet (Tucker and Lewis 1973; Bentler and Bonnet 1980; Bentler 1990). Because different measures of fit capture different elements of the fit of the model, it is appropriate to report a selection of different fit measures. Individual parameters of the model were examined

using R package and polychoric correlations within the estimated model in order to see how well the proposed model fits the driving theory. Due to resulting non-convergence problems, structural equation models were estimated based on Pearson's correlation matrix (considering items as being continuous) given that parametric methods show the interaction between variables more strongly.

\section{FINDINGS AND HYPOTHESES TESTING}

The results obtained from software R enabled the validation of 6 out of the 8 hypotheses that had been originally posed. Hypotheses with a high and statistically significant structural coefficient (beta) and goodness-of-fit indicators close to 1, with an RMSEA close to 0,05, are validated.

As hypothesized, trust $(\beta \mathrm{z}$ value=.4.8 $\operatorname{Pr}(>|\mathrm{z}|)$ 1,6e-06) has a significant and positive effect on interface quality (H2). However, contrary to our expectations, other network variables, density, centrality and power (H1 a, b, c) have no significant effect on trust. Knowledge construct either considered directly, squared (Tsui et al. 1992) or taken from difference index (Homburg and Jensen 2007), does not show any significant relationship with the quality of marketing and sales interface. Although it is not possible to conclude that there is not any significant relationship between knowledge and interface quality, it is readily apparent that when a high level of knowledge specialization is attained, the interface will have developed integrative tools that minimize this effect (Workman 1993). As hypothesized, teamwork $(\beta \mathrm{z}$ value $=3.3 \mathrm{Pr}(>|\mathrm{z}|) 8.9869 \mathrm{e}-04)$, information sharing $(\beta \mathrm{z}$ value=3.1 $\operatorname{Pr}(>|\mathrm{z}|) 2.5222 \mathrm{e}-03)$, formalization $(\beta \mathrm{z}$ value $=2.9 \operatorname{Pr}(>|\mathrm{z}| 3.9 \mathrm{e}-03)$ and joint planning $(\beta \mathrm{z}$ value=2.7 $\operatorname{Pr}(>|z|) 7.6684 \mathrm{e}-03)$ have a significant and positive effect on interface quality (H3a, H4a,b,c). As hypothesized, quality of the interface $(\beta \mathrm{z}$ value $=2.2 \operatorname{Pr}(>|\mathrm{z}|) 2.7528 \mathrm{e}-02)$, has a significant and positive effect on firm performance $(\mathrm{H} 5)$.

\section{CONCLUSION}

This study focuses on marketing and sales since these two functions play a key role in the company's performance. Our findings suggest that the quality of the marketing and sales interface is positively associated with business performance, and is consistent with empirical evidence and previous studies (Dewsnap et al. 2000, 2004; Rouziès et al. 2005; Le MeunierFitzHugh and Piercy 2007; Homburg and Jensen 2007; Homburg et al. 2008) conducted in Europe. They also enhance the importance of interface management on the firm's successful achievement of goals in Latin America. Our results also validate teamwork, information sharing, formalization, joint planning and quality of the interface dimensions, which have already been found to be relevant in the literature (Ruekert and Walker 1987; Piercy 1989; Jaworski and Kohli 1993; Cespedes 1996; Ellinger 2000; Dewsnap and Jobber 2004; Homburg and Jensen 2007; Homburg et al. 2007; Homburg et al. 2008) as dimensions playing a key role. Additionally, information exchange network variables are examined, characterizing network density, power and centrality, validating the trust construct and its positive relationship with interface quality (Wakabayashi, 2003). We believe that a significant contribution has been made to the existing literature, by combining two approaches which have not appeared simultaneously in any previous study: the multidimensional factor model related to the quality of interface and information exchange network approach variables. Since our analysis rests on a small number of respondents (although they represent $60 \%$ of the sample) and limited to survey data provided by a firm operating in the consumer goods industry, the applicability of our findings to other industries needs to be tested. Additional studies, using better measures of knowledge (sales and marketing) would yield more insights. Future research could also examine other network variables and study the way in which different organizational network mechanisms operate according to different cultural norms and market mechanisms. Despite these limitations, our study integrates the information exchange network approach to the marketing and sales interface management and validates models for Latin America, which have been previously tested in other continents. Our findings suggest that the main challenge for senior executives in charge of managing the value of a social network interface is to make sure marketing and sales teams continue to improve the quality of interface, building trust and developing planning, information transfer and teamwork skills. 
TABLES

Table 1: Descriptive statistics by construct

\begin{tabular}{|c|c|c|c|c|c|}
\hline Construct & Variables & $\mathrm{M}$ & SD & Alpha Cronbach & Source \\
\hline \multirow{6}{*}{$\begin{array}{c}\text { Relational } \\
\text { Embeddedness }\end{array}$} & Centrality Argentina & 14,2 & 4,7 & & \multirow{9}{*}{$\begin{array}{l}\text { Borgatti, Everett and Freeman } \\
\qquad(2002)\end{array}$} \\
\hline & Centrality Uruguay & 12,2 & 3,0 & & \\
\hline & Centrality Paraguay & 11,0 & 2,1 & & \\
\hline & Power Argentina & 16,8 & 22,7 & & \\
\hline & Power Uruguay & 4,6 & 4,1 & & \\
\hline & Power Paraguay & 3,3 & 2,5 & & \\
\hline \multirow{3}{*}{$\begin{array}{c}\text { Structural } \\
\text { Embeddedness }\end{array}$} & Density (\%) Argentina & 42 & 0,49 & & \\
\hline & Density (\%) Uruguay & 78 & 0,41 & & \\
\hline & Density (\%) Paraguay & 75 & 0,43 & & \\
\hline \multirow{3}{*}{ Trust } & Mutual trust & 3,91 & 0,84 & \multirow{3}{*}{0,85} & \multirow{3}{*}{ Wakabayashi (2003) } \\
\hline & Long term mutual trust & 4,05 & 0,79 & & \\
\hline & Mutual support & 4.33 & 0,71 & & \\
\hline \multirow{3}{*}{$\begin{array}{l}\text { Knowledge of } \\
\text { marketing }\end{array}$} & Knowledge of clients & 2,77 & 0,81 & \multirow{3}{*}{0,60} & \multirow{3}{*}{ Homburg et al. (2008) } \\
\hline & Knowledge of competitors & 3,91 & 0,78 & & \\
\hline & Knowledge of brands & 4,44 & 0,63 & & \\
\hline \multirow{3}{*}{$\begin{array}{c}\text { Knowledge of } \\
\text { sales }\end{array}$} & Knowledge of clients & 4,35 & 0,72 & \multirow{3}{*}{0,75} & \multirow{3}{*}{ Homburg et al. (2008) } \\
\hline & Knowledge of competitors & 3,95 & 0,62 & & \\
\hline & Knowledge of brands & 3,81 & 0,91 & & \\
\hline \multirow{8}{*}{ Teamwork } & Teamwork skills marketing & 4,09 & 0,84 & \multirow{8}{*}{0,85} & \multirow{8}{*}{$\begin{array}{l}\text { Cespedes (1996) } \\
\text { Homburg et al. (2008) }\end{array}$} \\
\hline & Teamwork skills sales & 4,12 & 0,70 & & \\
\hline & Communication skills marketing & 3,91 & 0,90 & & \\
\hline & Communication skills sales & 3,88 & 0,66 & & \\
\hline & Persuading skills marketing & 3,74 & 0,66 & & \\
\hline & Persuading skills sales & 3,74 & 0,73 & & \\
\hline & Conflict tolerance marketing & 3,28 & 0,70 & & \\
\hline & Conflict tolerance sales & 3,47 & 0,83 & & \\
\hline \multirow{3}{*}{$\begin{array}{l}\text { Information } \\
\text { Sharing }\end{array}$} & High speed information & 3,55 & 0,80 & \multirow{3}{*}{0,94} & \multirow{3}{*}{$\begin{array}{l}\text { Jaworski y Kohli (1993) } \\
\text { Homburg et al. (2008) }\end{array}$} \\
\hline & Proactive information & 3,14 & 0,94 & & \\
\hline & Relevant information & 3,42 & 0,91 & & \\
\hline \multirow{7}{*}{ Formalization } & Process trust & 3,88 & 0,70 & \multirow{7}{*}{0,85} & \multirow{7}{*}{$\begin{array}{l}\text { Ruekert and Walker (1987) } \\
\text { Dewsnap and Jobber (2002) } \\
\text { Homburg et al. (2008) }\end{array}$} \\
\hline & Written formalized process & 3,81 & 0,73 & & \\
\hline & Process development & 3,40 & 0,70 & & \\
\hline & Rules compliance & 3,84 & 0,62 & & \\
\hline & Rules effectiveness & 3,77 & 0,61 & & \\
\hline & Knowledge of process marketing & 3,86 & 0,70 & & \\
\hline & Knowledge of process sales & 3,81 & 0,84 & & \\
\hline & Joint planning & 4,05 & 0,49 & & \\
\hline & Joint decision & 3,93 & 0,51 & 087 & Piercy (1989) \\
\hline Joint planning & Joint implementation & 3,67 & 0,68 & 0,81 & Homburg et al. (2008) \\
\hline & Joint resolution & 3,56 & 0,91 & & \\
\hline & Frictionless collaboration & 3,56 & 0,91 & & \\
\hline & Coordinated decision & 3,91 & 0,65 & & \\
\hline & Coordinated activities & 3,81 & 0,76 & & Ellinger (2000) \\
\hline guality & Common objectives & 4,02 & 0,60 & 0,91 & Homburg and Jensen (2007) \\
\hline & Agreements compliance by sales & 3,88 & 0,73 & & Homburg et al. (2008) \\
\hline & Agreements compliance by mktg & 3,74 & 0,66 & & \\
\hline & Relationship satisfaction & 3,91 & 0,90 & & \\
\hline & Profitability result vs competitors & 3,63 & 1,07 & & Homburg and Jensen (2007) \\
\hline $\begin{array}{l}\text { Business } \\
\text { performance }\end{array}$ & Turnover growth vs competitors & 4,00 & 0,85 & 0,76 & Homburg et al. (2008) \\
\hline & Market share vs competitors & 3,65 & 0,95 & & Trade audits (Nielsen, CCR) \\
\hline
\end{tabular}


Table 2: Effects of network embeddedness, structural linkages, information and knowledge on Interface Quality and Business Performance

\begin{tabular}{|l|c|c|c|c|c|c|c|c|l|}
\hline \multirow{2}{*}{ Construct effect } & $\begin{array}{c}\text { Null } \\
\text { Model }\end{array}$ & \multicolumn{7}{|c|}{ Model } & \\
\cline { 2 - 9 } & $\begin{array}{c}\text { Chi- } \\
\text { square }\end{array}$ & $\begin{array}{c}\text { Chi- } \\
\text { square }\end{array}$ & $\begin{array}{c}\text { Beta } \\
\text { Z } \\
\text { value }\end{array}$ & $\begin{array}{c}\text { Beta } \\
\operatorname{Pr}(>|\mathrm{z}|)\end{array}$ & $\begin{array}{c}\text { Goodness } \\
\text { of fit }\end{array}$ & RMSEA & $\begin{array}{c}\text { BB } \\
\text { NFI }\end{array}$ & $\begin{array}{c}\text { Tucker } \\
\text { Lewis } \\
\text { NNFI }\end{array}$ & Hypotheses \\
\hline Network embeddedness & 185,53 & 40,52 & $<2$ & & & & & & H1 (a, b, c) \\
Trust & 250,30 & 34,72 & 4,8 & $1,6 \mathrm{e}-06$ & 0,874 & 0,074 & 0,861 & 0,957 & $\mathrm{H} 2$ \\
Teamwork & 407,52 & 128,47 & 3,3 & $8,9 \mathrm{e}-04$ & 0,749 & 0,137 & 0,685 & 0,775 & $\mathrm{H} 3 \mathrm{a}$ \\
Information & 300,36 & 38,94 & 3,1 & $2,5 \mathrm{e}-03$ & 0,874 & 0 & 0,870 & 1,000 & $\mathrm{H} 4 \mathrm{a}$ \\
Joint planning & 284,30 & 46,42 & 2,7 & $7,7 \mathrm{e}-03$ & 0,857 & 0 & 0,837 & 1,016 & $\mathrm{H} 4 \mathrm{~b}$ \\
Formalization & 385,91 & 89,68 & 2,9 & $3,9 \mathrm{e}-03$ & 0,805 & 0,044 & 0,768 & 0,970 & $\mathrm{H} 4 \mathrm{c}$ \\
Interface quality & 176,07 & 16,40 & 2,2 & $2,8 \mathrm{e}-02$ & 0,925 & 0 & 0,907 & 1,081 & $\mathrm{H} 5$ \\
\hline
\end{tabular}

\section{REFERENCES}

Bentler, P.M. 1990. “Comparative fit indexes in structural models.” Psychological Bulletin 107 (2): 238-246.

Bentler, P.M. and D.G. Bonett. 1980. "Significance tests and goodness-of-fit in the analysis of covariance structures." Psychological Bulletin (88): 588-600.

Betts, S.C. and M.D. Stouder. 2004. "The network perspective in organization studies: Network organizations or network analysis?." Academy of Strategic Management Journal (3): 1-20.

Bonacich, P. 1991. "Simultaneous group and individual centralities." Social Networks (13): 155-168.

Borgatti, S.P. and M.G. Everett and L.C. Freeman. 2002. Ucinet for Windows: Software for social network analysis. Harvard, MA: Analytic Technologies.

Borgatti, S.P. and Li X. 2009. "On Social Network Analysis in a Supply Chain Context.” Journal of Supply Chain Management (April): 1-17.

Borgatti, S. P. and A. Mehra and D.J. Brass and G. Labianca. 2009. "Network Analysis in the Social Sciences." Science 323 (5916): 892-895.

Carter, C.R. and L.M. Ellram and W.L. Tate. 2007. "The Use of Social Network Analysis in Logistics Research.” Journal of Business Logistics 28 (1): 137-168.

Cespedes, F.V. 1995. Concurrent Marketing: Integrating Product, Sales, and Service. Boston: Harvard Business School Press.

Cespedes, F.V. 1996. "Beyond Teamwork: How the Wise Can Synchronize.” Marketing Management 5 (1): $24-37$.

Child, J. and D. Faulkner. 1998. Strategies of Cooperation. Oxford, UK: Oxford University Press.

Costello, A.B. and J.W. Osborne. 2005. "Best practices in exploratory factor analysis: Four recommendations for getting the most from your analysis." Practical Assessment Research \& Evaluation 10 (7): 1-9.

Day, G.S. and D.B. Montgomery. 1999. "Charting new directions for marketing." Journal of Marketing 63 (Special issue): 3-13.

Dawes, P. L. and G.R. Massey. 2005. "Antecedents of Conflict in Marketing's Cross-Functional Relationship with Sales." European Journal of Marketing 14 (11/12): 1327-1344. 
Dawes, P. L. and G.R. Massey. 2006. "A study of relationship effectiveness between marketing and sales managers in business markets.” Journal of Business \& Industrial Marketing 21 (6): 346-360.

Dawes, P. L. and G.R. Massey. 2007. "Personal characteristics, trust, conflict, and effectiveness in marketing/sales working relationships.” European Journal of Marketing 41 (9/10): 1117-1145.

Dawes, P. L. and G.R. Massey. 2007. "The antecedents and consequence of functional and dysfunctional conflict between marketing managers and sales managers.” Industrial Marketing Management 36 (8): 1118-1129.

Dewnsnap, B. and D. Jobber. 2000. "The Sales-Marketing Interface in Consumer Packaged- Goods Companies: A Conceptual Framework.” Journal of Personal Selling \& Sales Management XX (2): 109-119.

Dewsnap, B. and D. Jobber. 2002. “A Social Psychological Model of Relations Between Marketing and Sales.” European Journal of Marketing 36 (7/8): 874-94.

Dewsnap, B. and A.L. Souchon and J. W. Cadogan and D.B. Procter. 2004. "Marketing information use and organizational performance: the mediating role of responsiveness.” Journal of Strategic Marketing 12 (4): 231-242.

Ellinger, A. E. 2000. "Improving Marketing/Logistics Cross-Functional Collaboration in the Supply Chain." Industrial Marketing Management 29 (1): 85-96.

Fox, J. 2006. “Structural Equation Modeling With the SEM Package in R” Structural Equation Modeling 13 (3): $465-486$.

Glückler, J. 2005. "Making embeddedness work: social practice, institutions, in foreign consulting markets." Environment and Planning A (37): 1727-1750.

Granovetter, M. 1985. "Economic action and social structure: A theory of embeddedness." American Journal of Sociology 91 (3): 481-510.

Hanneman, R.A. 2002. Introducción a los métodos de análisis de redes. Retrieved March 15, 2009 from http://wizard.ucr.edu/ rhannema/networks/text/textindex.html

Hess, M. 2004. "Spatial'relationships? Towards a reconceptualization of embeddedness." Progress in Human Geography (28): 165-186.

Homburg, C. and J.P. Jr. Workman and H. Krohmer. 1999. "Marketing's Influence Within the Firm." Journal of Marketing (63): 1-17.

Homburg, C. and J.P. Jr. Workman and O. Jensen. 2000. "Fundamental Changes in Marketing Organization: The Movement Towards a Customer-Focused Organizational Structure.” Journal of the Academy of Marketing Science 28 (4): $459-79$.

Homburg, C. and M. Grozdanovic and M. Klarmann. 2007. "Responsiveness to Customers and Competitors: The Role of Affective and Cognitive Organizational Systems.” Journal of Marketing (71): 18-38.

Homburg, C. and O. Jensen. 2007. "The Thought Worlds of Marketing and Sales: Which Differences Make a Difference?" Journal of Marketing (71): 124-142.

Homburg, C. and O. Jensen and H. Krohmer. 2008. "Configurations of Marketing and Sales: A Taxonomy." Journal of Marketing 72 (2): 133-154.

Jaworski, B.J. and A.K. Kohli. 1993. "Market Orientation: Antecedents and Consequences.” Journal of Marketing (57): 5370 .

Kotler, P. and N. Rackham and S. Krishnaswamy. 2006. "Ending the War Between Sales and Marketing." Harvard Business Review 84 (7/8): 68-78. 
Krackhardt, D. 1990. "Assessing the political landscape: Structure, cognition and power in organizations." Administrative Science Quarterly (35): 342-369.

Le Meunier-FitzHugh, K. and N.F. Piercy. 2007. "Does collaboration between sales and marketing affect business performance?.” Journal of Personal Selling \& Sales Management XXVII (3): 207-220.

Mertler, C.A. and R.A. Vannata. 2005. Advanced and Multivariate Statistical Methods. Third Edition. Glendale: Pyrczak Publishing

Montgomery, D.B. and F.E. Jr. Webster. 1997. "Marketing's Inter-functional Interfaces: The MSI Workshop on Management of Corporate Fault Zones." Journal of Market Focused Management 2 (1): 7-26.

Oliden, P.E. and B.D. Zumbo. 2008. "Coeficientes de fiabilidad para escalas de respuesta categorical ordenada." Psicothema (20): 896-901.

Piercy, N. 1989. "The Power and Politics of Sales Forecasting: Uncertainty Absorption and the Power of the Marketing Department." Journal of the Academy of Marketing Science 17 (2): 109-120

Powell, W.W. 1990. "Neither market nor hierarchy: Network forms of organization." Research in Organizational Behaviour (12): 295-336.

Rodriguez, C.M. and D.T. Wilson. 1999. "Relationship Bonding and Trust as Foundation for Commitment in International Strategic Alliances, USA-Mexico: A Latent Variable Structural Modeling Approach.” ISBM Report 21. Philadelphia: Institute for the Study of Business Markets . Pennsylvania State University.

Rouziès, D. and E. Anderson and A.K. Kohli and R.E. Michaels and B.A Weitz and A.A. Zoltners. 2005. "Sales and marketing integration: a proposed framework.” Journal of Personal Selling \& Sales Management XXV (2): 113-122.

Ruekert, R.W. and O.C. Walker. 1987. "Marketing's interaction with other functional units: a conceptual framework and empirical evidence." Journal of Marketing (51): 1-19.

Tsui, A.S. and T.D. Egan and C.A. O'Reilly. 1992. "Being Different: Relational Demography and Organizational Commitment." Administrative Science Quarterly 37 (4): 549-579.

Tucker, L. and C.Lewis.1973. "A reliability coefficient for maximum likelihood factor analysis.” Psychometrika (38): 1-10

Uzzi, B. 1996. "The sources and consequences of embeddedness for the economic performance of organizations". American Sociological Review (61): 674-698.

Uzzi, B. 1997. "Social structure and competition in interfirm networks: The paradox of embeddedness." Administrative Science Quarterly (42): 35-67.

Wakabayashi, N. 2003. "Relational Trust and Embeddedness in Interorganizational Networks: An Analysis of Quality Control Manager Networks in Japanese Buyer-Supplier Relations." Working Paper 71. Kyoto: Faculty of Economics. Kyoto University.

Wasserman, S. and K. Faust. 2008. Social Network Analysis. New York: Cambridge University Press.

Webster, F.E. Jr. 1997. "The Future Role of Marketing in the Organization." In Reflections on the Futures of Marketing. Eds. D.R. Lehmann and K.E. Jocs. Cambridge, MA: Marketing Science Institute.

Workman, J.P and C. Homburg and K. Gruner. 1998. "Marketing Organization: An Integrative Framework of Dimensions and Determinants" Journal of Marketing 62 (July): 21-41. 